\title{
ARTICLE
}

\section{Evaluation of the thermal stability under air of the uranyl peroxide nanocluster $\left(\mathrm{NH}_{4}\right)_{40}\left[\left(\mathrm{UO}_{2}\right)_{32}\left(\mathrm{O}_{2}\right)_{40}(\mathrm{OH})_{24}\right] \cdot n \mathrm{H}_{2} \mathrm{O}$}

\author{
Paul-Henri Imbert $^{\mathrm{a}}$, Olivier Tougait ${ }^{\mathrm{a}}$, Philippe Devaux ${ }^{\mathrm{a}}$, Natacha Henry ${ }^{\mathrm{a}}$, Marine Ellart ${ }^{\mathrm{a}}$, Francis Abraham ${ }^{\mathrm{a}}$ \\ and Jérémy Nos ${ }^{b}$ \\ ${ }^{a}$ Univ Lille, UCCS - UMR CNRS 8181, ENSCL-USTL, BP 90108, 59652 Villeneuve d'Ascq Cedex, France; ${ }^{b}$ AREVA-NC,Tour \\ AREVA, 1 Place Jean Millier, 92084 Paris La Défense, France
}

\begin{abstract}
The synthesis, characterization and thermal decomposition of the uranyl peroxide nanocluster $\left(\mathrm{NH}_{4}\right)_{40}\left[\left(\mathrm{UO}_{2}\right)_{32}\left(\mathrm{O}_{2}\right)_{40}(\mathrm{OH})_{24}\right] \cdot \mathrm{nH}_{2} \mathrm{O}$, designated as U32R-NH , are presented for a series of temperatures ranging from 20 to $800^{\circ} \mathrm{C}$. The handlings and annealing were carried out under air and the post-treatment characterizations were managed back to room temperature. The identification of the intermediate compounds was achieved by chemical analysis, infrared spectroscopy and powder X-ray diffraction. The proposed decomposition scheme up to $\mathrm{U}_{3} \mathrm{O}_{8}$ comprises three main steps; $(i)$ the low temperature range, from room temperature to $190^{\circ} \mathrm{C}$, is characterized by the loss of the molecular species, water molecules, ammonium and peroxo ions, (ii) the intermediate temperature range, from 190 to $590^{\circ} \mathrm{C}$, involves mostly structural rearrangements and release of oxygen and nitrogen species, and (iii) the high temperature range, above $590^{\circ} \mathrm{C}$, which is associated to the $\mathrm{UO}_{3}-\mathrm{U}_{3} \mathrm{O}_{8}$ transition accompanied with $\mathrm{O}_{2}$ release. The thermal treatment up to $800^{\circ} \mathrm{C}$ does not alter the morphological features of the initial powder suggesting a pseudomorphic decomposition. Upon ageing or heating, the starting compound, $\left(\mathrm{NH}_{4}\right)_{40}\left[\left(\mathrm{UO}_{2}\right)_{32}\left(\mathrm{O}_{2}\right)_{40}(\mathrm{OH})_{24}\right] . n \mathrm{H}_{2} \mathrm{O}$, readily loses its crystallinity.
\end{abstract}

Keywords: thermal decomposition; chemical analysis; infrared spectrum; powder X-ray diffraction; uranium oxide; pseudomorphic decomposition

\section{Introduction}

Mixed $\mathrm{U}^{6+} / \mathrm{Pu}^{4+}$ solid compounds precipitated from aqueous solutions are regarded as possible precursors for MOX fabrication [1]. To this respect, the recent advances on the synthesis and structural characterization of uranyl peroxide nanoclusters containing rare-earth cations [2] afford the opportunity of an innovative fabrication process, interesting to explore. This family of compounds is characterized by a framework built from uranyl polyhedra bridged through peroxide or hydroxide ligands $[3,4]$ that create cavities where the countercations reside. Their high structural and chemical flexibilities yielding assemblies described as nanoclusters, afford about 40 original arrangements reported in the literature.

Among them, the uranyl peroxide, $\left(\mathrm{NH}_{4}\right)_{40}\left[\left(\mathrm{UO}_{2}\right)_{32}\left(\mathrm{O}_{2}\right)_{40}(\mathrm{OH})_{24}\right] \cdot n \mathrm{H}_{2} \mathrm{O}$, denoted in the following as $\mathrm{U} 32 \mathrm{R}-\mathrm{NH}_{4}$, readily precipitates at room temperature with a sharp selectivity [5]. Its high anionic moiety associated to its crown shape make it rather promising for intercalation chemistry. Very recently we successfully exchanged the $\mathrm{NH}_{4}^{+}$by $\mathrm{Nd}^{3+}$ or $\mathrm{Th}^{4+}$

*Corresponding author. Email: olivier.tougait@univ-lille1.fr cations [6], allowing prospective research for the fabrication of mixed fuel or target, combining uranium and trans-uranium elements by considering $\mathrm{Th}^{4+}$ and $\mathrm{Nd}^{3+}$ as a surrogate of $\mathrm{Pu}^{4+}$ and $\mathrm{Am}^{3+}$, respectively. The scientific objective of our study is to demonstrate the potentiality of these nanoclusters as suitable precursors for the preparation of single phase fluorine type mixed oxides pellets, with optimized microstructure.

As a first step of this exhaustive study, we present here the investigation on the stability behaviors of the nano-uranyl cluster U32R-NH4 $\mathrm{NH}_{4}$ The thermal decomposition pathway was studied by ex-situ annealing at key temperatures by means of chemical analysis, infrared spectroscopy and powder X-ray diffraction on the intermediate reaction products.

\section{Experimental section}

\section{1. $\mathrm{U} 32 \mathrm{R}-\mathrm{NH}_{4}$ synthesis}

The ammonium uranyl peroxide nanocluster $\left(\mathrm{NH}_{4}\right)_{40}\left[\left(\mathrm{UO}_{2}\right)_{32}\left(\mathrm{O}_{2}\right)_{40},(\mathrm{OH})_{24}\right] \cdot n \mathrm{H}_{2} \mathrm{O}$, denoted as $\mathrm{U} 32 \mathrm{R}-\mathrm{NH}_{4}$, was synthesized by adding a solution of uranyl nitrate hexahydrate $\left(\mathrm{UO}_{2}\left(\mathrm{NO}_{3}\right)_{2} \cdot 6 \mathrm{H}_{2} \mathrm{O}, 0.34 \mathrm{M}\right)$ and hydrogen peroxide $\left(\mathrm{H}_{2} \mathrm{O}_{2}, 9.79 \mathrm{M}\right)$. Under 
continuous stirring, a solution of ammonium hydroxide $\left(\mathrm{NH}_{4} \mathrm{OH}, 4 \mathrm{M}\right)$ was added until the $\mathrm{pH}$ reaches 10 . After precipitation and ageing time at room temperature of about 10 hours, the solid was filtered under vacuum and washed with $5 \mathrm{ml}$ of ethanol. Finally, the powder was dried at room temperature.

\subsection{Heat treatment}

Annealing of batches of powders was carried out for 16 hours under air with a heating ramp of $5^{\circ} \mathrm{Cmin}^{-1}$ up to the target temperature. For temperatures up to $200^{\circ} \mathrm{C}$, the calcinations were performed in computer controlled ovens whereas for temperatures above $200^{\circ} \mathrm{C}$, they were performed in resistance furnaces.

\subsection{Scanning electron microscopy (SEM)}

Scanning Electron Microscopy (SEM) was carried out with a Hitachi S4700 SEM FEG microscope.

\subsection{Thermogravimetric (TGA) and differential thermal analyses (DTA)}

Thermogravimetric and differential thermal analyses were carried out with a SETARAM 92 system. The sample was placed in an alumina crucible and heated up to $800{ }^{\circ} \mathrm{C}$, in air, with a scan rate of $5^{\circ} \mathrm{Cmin}^{-1}$.

\subsection{Chemical analyses}

The inductively coupled plasma atomic emission spectroscopy (ICP-AES) analysis of $U$ was conducted using a VARIAN Vista-Pro instrument. About $10 \mathrm{mg}$ of powder was dissolved in nitric acid $\left(\mathrm{HNO}_{3}, 8 \mathrm{M}\right)$. Subsequent dilutions were carried out to reach a uranyl ion concentration in the range 20 to $40 \mathrm{ppm}$.

The weight percentage of ammonium ions was determined by a metric $\mathrm{pH}$ assay (Kjeldahl method). The kjeldahl distiller used is the Kjelflex-360. The automatic titrator is Titroline 5000. The weight percentage of peroxide ions was determined by redox titration.

\subsection{Spectroscopic measurement}

Infrared spectra were measured on PerkinElmer Spectrum Two spectrometer between 4000 and $400 \mathrm{~cm}^{-1}$, equipped with a diamond attenuated total reflectance (ATR) accessory.

\subsection{Powder X-ray diffraction (XRD) analysis}

Room temperature XRD diagrams were collected with a D8 Advance Bruker diffractometer $(\Theta-\Theta$ mode, $\mathrm{CuK} \alpha$ radiation) equipped with a Vantec1 linear position sensitive detector (PSD). Each diagram was recorded in the range $5-60^{\circ}(2 \Theta)$, with a step of $0.02^{\circ}$ and with a speed of $0.5 \mathrm{~s} /$ step.

\section{Results and discussion}

Figure 1 shows the thermal decomposition under air of the compound U32R-NH . The thermogravimetric curve and its derivative reveal three significant weight losses as outlined by the calculated weigh percent of the intermediate compositions. The first decomposition step occurs below about $190^{\circ} \mathrm{C}$ for a mass loss of 17 wt $\%$. The second one, which is characterized by a continuous weight loss of $6 \%$ and a featureless derivative extends up to about $590^{\circ} \mathrm{C}$. The last decomposition step takes place at $590^{\circ} \mathrm{C}$ with a $3.5 \mathrm{wt} \%$ loss.

The differential thermal analysis (DTA) curve indicates a more tangled scheme associated to five distinct thermal effects. The first decomposition step, below about $190^{\circ} \mathrm{C}$ is characterized by two thermal accidents, at $70^{\circ} \mathrm{C}$ and about $150^{\circ} \mathrm{C}$, coupled to endodermic and exothermic peaks respectively. The second decomposition step ranges from 190 to $590^{\circ} \mathrm{C}$ and exhibits three successive exothermic peaks with onset temperature at about $220^{\circ} \mathrm{C}, 280^{\circ} \mathrm{C}$ and $380^{\circ} \mathrm{C}$. The third decomposition step occurs as a single transition at about $590^{\circ} \mathrm{C}$. This last endotherm can be readily associated to the transformation of $\mathrm{UO}_{3}$ to $\mathrm{U}_{3} \mathrm{O}_{8}$.

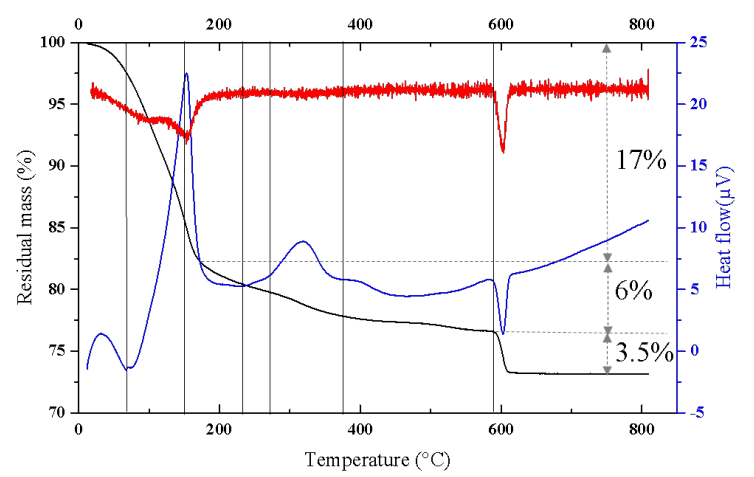

Figure 1. Decomposition of U32R-NH $\mathrm{NH}_{4}$ in air: TG trace is the black curve and its derivative is the red curve; DTA signal is in blue. Vertical thin lines point out the main transformations.

Ex-situ annealing temperatures were chosen below and above each thermal accident, roughly corresponding to shallow plateaus of the TGA curve. They were determined as $70^{\circ} \mathrm{C}, 200^{\circ} \mathrm{C}, 350^{\circ} \mathrm{C}, 470^{\circ} \mathrm{C}, 570^{\circ} \mathrm{C}$ and $800^{\circ} \mathrm{C}$. The heat-treated samples were used to identify and to characterize the intermediate phases of the thermal decomposition of U32R-NH $\mathrm{NH}_{4}$ peroxide in order to support a stepwise scheme.

Figure 2 shows the samples retrieved after each annealing. The evolution of the color follow the typical trend of yellow, orange, red, brown, green and black which is associated to the reduction from $\mathrm{U}^{6+}$ to $\mathrm{U}^{4+}$ of uranium ions and their contents in solids.

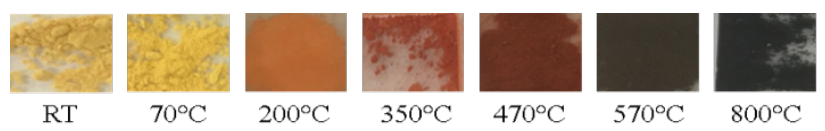

Figure 2. Samples retrieved from stepwise annealing, of the intermediate reaction powders of $\mathrm{U} 32 \mathrm{R}-\mathrm{NH}_{4}$.

Figure 3 displays SEM images of each heat-treated powder which more likely appears as aggregates of submicronic particles and micrometric single crystals with elongated rice seed shape. The samples description 
remains the same for all the annealed powder indicating that thermal treatment does not alter the powder morphology in agreement with a possible pseudomorphic decomposition of the U32R-NH 4 material.

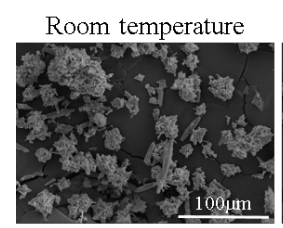

$350^{\circ} \mathrm{C}$

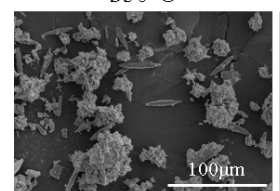

$800^{\circ} \mathrm{C}$

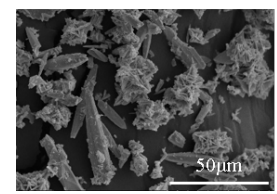

Figure 3. SEM images, collected in secondary electron mode, of intermediate reaction powders of $\mathrm{U} 32 \mathrm{R}-\mathrm{NH}_{4}$ produced by heating treatment at selected temperatures for 16 hours.

The IR spectra of $\mathrm{U} 32 \mathrm{R}-\mathrm{NH}_{4}$ and the products obtained by heating the solid at 70, 200, 350, 470, 570 and $800^{\circ} \mathrm{C}$ and cooling to room temperature are gathered in Figure 4. In agreement with the crystalline structure, $\left(\mathrm{NH}_{4}\right)_{40}\left[\left(\mathrm{UO}_{2}\right)_{32}\left(\mathrm{O}_{2}\right)_{40}(\mathrm{OH})_{24}\right] \cdot \mathrm{nH}_{2} \mathrm{O}$, the IR spectra indicate absorption bands featuring the three main constitutional groups, $\mathrm{NH}_{4}^{+}, \mathrm{UO}_{2}^{2+}$ and $\mathrm{H}_{2} \mathrm{O}$. The room temperature spectrum exhibits a broad band ranging from 3600 to $2700 \mathrm{~cm}^{-1}$ which may be assigned to the various stretching modes of $\mathrm{H}_{2} \mathrm{O}$ and $\mathrm{NH}_{4}^{+}$, whereas the shaper absorption bands in the range $1650-1200 \mathrm{~cm}^{-1}$ may be associated to the bending modes of these molecules. The strong peak in the neighborhood of $900 \mathrm{~cm}^{-1}$ along with its shoulder at about $850 \mathrm{~cm}^{-1}$ are undoubtedly due to the symmetric and asymmetric vibrations of the uranyl ion [7]. Absorption bands featuring the vibrational stretching modes of the peroxo ion and the $\mathrm{UO}_{2}^{2+}-$ $\mathrm{O}_{2}^{2-}$ linkage could not be detected. The IR spectra of the stepwise annealed samples were used as footprint of the release of the $\mathrm{H}_{2} \mathrm{O}$ and $\mathrm{NH}_{3}$ molecules and the structural evolution of the $\mathrm{UO}_{2}^{2+}$ geometry. The vanishing of the absorption bands in the range $3600-2700 \mathrm{~cm}^{-1}$ indicates that the loss of the $\mathrm{H}_{2} \mathrm{O}$ and $\mathrm{NH}_{4}^{+}$arises below $200^{\circ} \mathrm{C}$. The weak but apparent absorption bands between $1650-1200 \mathrm{~cm}^{-1}$ in the $200^{\circ} \mathrm{C}$ spectrum may be ascribed to the $\mathrm{U}-\mathrm{OH}$ and $\mathrm{U}-\mathrm{NH}$ bending vibrations [8]. Starting from $200^{\circ} \mathrm{C}$, a clear evolution of the U-O vibration modes arises, outlined by the lowering of the $900-850 \mathrm{~cm}^{-1}$ narrow bands and the growing of the $860-600 \mathrm{~cm}^{-1}$ thick bands. It results from the elongation of the $\left(\mathrm{U}=\mathrm{O}_{y l}\right)$ distances and angles toward a (U-O) bonds of typical coordination polyhedron [8].

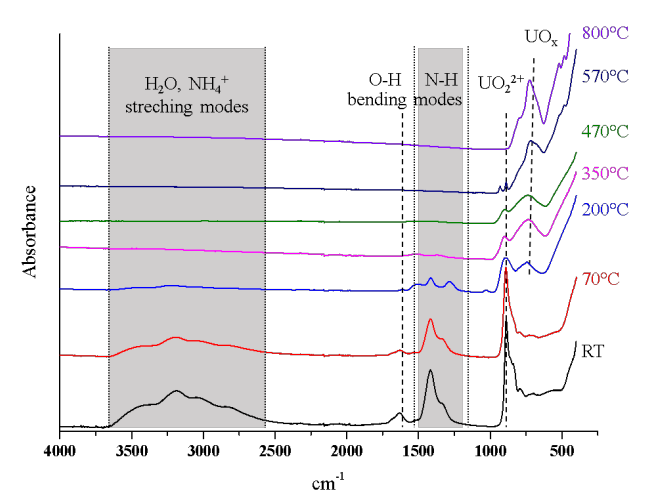

Figure 4. IR spectra of samples from stepwise annealing at the key temperatures of intermediate reaction phases of U32R-NH $\mathrm{NH}_{4}$

Figure 5 shows the powder X-ray patterns of the stepwise samples annealed under air. Absence of diffracted intensity in patterns from room temperature to $470^{\circ} \mathrm{C}$ indicates amorphous phases emphasizing the loss of the U32R-NH$H_{4}$ crystallinity after ageing for $10 \mathrm{~h}$.

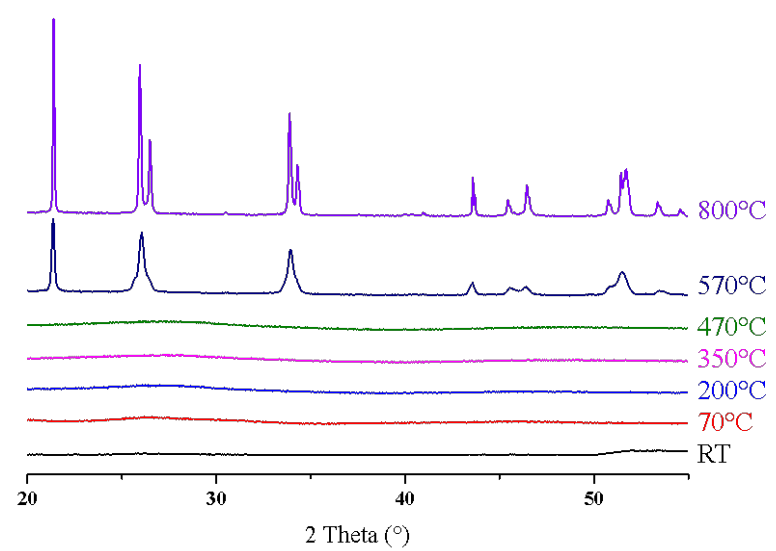

Figure 5. Powder X-ray diffraction patterns of samples retrieved from different temperatures.

The diffraction pattern of the $570^{\circ} \mathrm{C}$ heat-treated sample collected back to room temperature was indexed by considering a mixture of two oxide phases, $(i) \alpha \mathrm{UO}_{3}$ with its commonly accepted average description in hexagonal symmetry [9] and (ii) $\mathrm{UO}_{2.9}$ having an orthorhombic symmetry [10] with the refined parameters $a=6.912(1) \AA, b=3.910(1) \AA, c=4.153(1) \AA$. The $800^{\circ} \mathrm{C}$ pattern was fully indexed with the $\alpha \mathrm{U}_{3} \mathrm{O}_{8}$ in the $\mathrm{C} 2 \mathrm{~mm}$ orthorhombic space group, in agreement with [11].

The results of the chemical analyses of the annealed samples are presented in Table 1 . They clearly show the vanishing of the peroxo ions below $200^{\circ} \mathrm{C}$ and the continuous decrease of the ammonium ions up to $350^{\circ} \mathrm{C}$.

\section{Conclusion}

Results of thermal decomposition studies of the solid are summarized in Table 1. The correlation of the chemical, infrared and powder X-ray diffraction 
Table 1. Summary of the results of chemical, infrared, powder-XRD analyses for the key temperatures.

\begin{tabular}{|c|c|c|c|c|}
\hline Temperature & $\begin{array}{l}\text { Identification of } \\
\text { active species in } \\
\text { Infrared }\end{array}$ & $\begin{array}{l}\text { Crystalline } \\
\text { phases XRD }\end{array}$ & $\begin{array}{l}\text { Chemical } \\
\text { (\% weight) }\end{array}$ & Proposed phases \\
\hline RT & $\begin{array}{c}\mathrm{NH}_{4}^{+}, \mathrm{H}_{2} \mathrm{O}, \\
\mathrm{N}-\mathrm{H}, \mathrm{O}-\mathrm{H}, \\
\mathrm{UO}_{2}{ }^{2+}\end{array}$ & \multirow{5}{*}{ amorphous } & $\begin{array}{l}\mathrm{NH}_{4}^{+}=5.1 \\
\mathrm{O}_{2}{ }^{2-}=7.5\end{array}$ & $\left(\mathrm{NH}_{4}\right)_{40}\left[\left(\left(\mathrm{UO}_{2}\right)_{32}\left(\mathrm{O}_{2}\right)_{40}(\mathrm{OH})_{24}\right)\right] \cdot \mathrm{nH}_{2} \mathrm{O}$ \\
\hline $7^{\circ} \mathrm{C}$ & $\begin{array}{c}\mathrm{NH}_{4}^{+}, \mathrm{H}_{2} \mathrm{O} \\
\mathrm{N}-\mathrm{H}, \mathrm{O}-\mathrm{H} \\
\mathrm{UO}_{2}{ }^{2+}\end{array}$ & & $\begin{array}{l}\mathrm{NH}_{4}^{+}=3.9 \\
\mathrm{O}_{2}{ }^{2-}=5.8\end{array}$ & \multirow{4}{*}{$\begin{array}{c}\text { amorphous } \\
\left(\mathrm{NH}_{4}\right) \mathrm{UO}_{3} \\
a m \mathrm{UO}_{3}\end{array}$} \\
\hline $200^{\circ} \mathrm{C}$ & $\begin{array}{c}\mathrm{O}-\mathrm{H}, \mathrm{N}-\mathrm{H} \\
\mathrm{UO}_{2}{ }^{2+}, \mathrm{U}-\mathrm{O}\end{array}$ & & $\begin{array}{l}\mathrm{NH}_{4}^{+}=1.3 \\
\mathrm{O}_{2}{ }^{2-}=0.1\end{array}$ & \\
\hline $350^{\circ} \mathrm{C}$ & $\begin{array}{l}\mathrm{N}-\mathrm{H} \\
\mathrm{U}-\mathrm{O} \\
\end{array}$ & & $\mathrm{NH}_{4}^{+}=0.5$ & \\
\hline $470^{\circ} \mathrm{C}$ & $\mathrm{U}-\mathrm{O}$ & & & \\
\hline $\mathbf{5 7 0}^{\circ} \mathrm{C}$ & $\mathrm{U}-\mathrm{O}$ & $\alpha \mathrm{UO}_{3}+\mathrm{UO}_{2.9}$ & & $\alpha \mathrm{UO}_{3}+\mathrm{UO}_{2.9}$ \\
\hline $800^{\circ} \mathrm{C}$ & $\mathrm{U}-\mathrm{O}$ & $\alpha \mathrm{U}_{3} \mathrm{O}_{8}$ & & $\alpha \mathrm{U}_{3} \mathrm{O}_{8}$ \\
\hline
\end{tabular}

analyses of annealed samples at key temperatures in support of the thermal analysis allows to propose the thermal decomposition scheme of U32R-NH $\mathrm{NH}_{4}$. The TGA curve shows a substantial weight loss up to $190^{\circ} \mathrm{C}$, corresponding to the loss of water, ammonium and peroxo species. Upon heating to $590^{\circ} \mathrm{C}$, the TGA curve displays three small weight losses which may be ascribed to the release of elemental $\mathrm{N}$ or $\mathrm{O}$ species $(\mathrm{NH}+$ or $\mathrm{OH}+$ ) that are structurally bonded to $\mathrm{U}$ atoms. The structural rearrangement is in line with the three exothermic peaks observed in DTA curve. At $590^{\circ} \mathrm{C}$, $\mathrm{UO}_{3}$ undergoes transformation to $\mathrm{U}_{3} \mathrm{O}_{8}$ which is associated to an endothermic peak. A total mass loss of $26.5 \%$ is observed experimentally during thermal decomposition, which is in agreement with the calculated one of $25.5 \%$ from $\left(\mathrm{NH}_{4}\right)_{40}\left[\left(\mathrm{UO}_{2}\right)_{32}\left(\mathrm{O}_{2}\right)_{40}(\mathrm{OH})_{24}\right] \cdot \mathrm{nH}_{2} \mathrm{O}$ (with $\mathrm{n}=56$ ) to $\mathrm{U}_{3} \mathrm{O}_{8}$.

The indexation of the X-ray pattern of the sample annealed at $570^{\circ} \mathrm{C}$ with two uranium trioxide phases violates the Gibbs rule for a binary system, at a given partial oxygen pressure. It suggests a possible re-oxidation of the $570^{\circ} \mathrm{C}$ stable phase upon cooling in air [12] or the presence of light molecules stabilizing one of these crystalline forms [13]. In order to study the thermal decomposition of U32R-NH 4 , in-situ analyses are required.

\section{Acknowledgements}

This work was mainly carried out in the Joint Research Laboratory LR4CU AREVA NC - CNRS Univ-Lille - ENSCL. P-H. Imbert acknowledges AREVA NC and Univ-Lille for Ph-D grant financial support.

\section{References}

[1] F. Abraham, B. Arab-Chapelet, M. Rivenet, C. Tamain and S. Grandjean, Actinide oxalates, solid state structures and applications, Coord. Chem. Rev. 266-267 (2014), pp.28-68.
[2] F. Blanchard, F. Abraham, M. Rivenet, S. Grandjean, N. Vigier and I. Hablot, Patent FR3015453, WO2015091753, (2015).

[3] J. Qiu and P.C. Burns, Clusters of actinides with oxide, peroxide, or hydroxide bridges, Chem. Rev. 113 (2013), pp. 1097-1120.

[4] F. Blanchard, M. Ellart, M. Rivenet, N. Vigier, I. Hablot, B. Morel, S. Grandjean and F. Abraham, Role of ammonium ions in the formation of ammonium uranyl peroxides and uranyl peroxo-oxalates, Cryst. Growth Des. 16 (2016), pp. 200-209.

[5] G.E. Sigmon and P.C. Burns, Rapid self-assembly of uranyl polyhedra into crown clusters, J. Am. Chem. Soc. 133 (2011), pp.9137-9139.

[6] F. Blanchard, M. Ellart, M. Rivenet, N. Vigier, I. Hablot, B. Morel, S. Grandjean and F. Abraham, Neodymium uranyl peroxide synthesis by ion exchange on ammonium uranyl peroxide nanoclusters, Chem. Comm. 52 (2016), pp.3947-3950.

[7] N.H. Rofail, Infrared and x-ray diffraction spectra of ammonium uranyl carbonate, Mater. Chem. Phys. 36 (1994), pp. 241-245.

[8] R.L. Frost, J. Čejka, G.A. Ayoko and M.L. Weier, Vibrational spectroscopic study of hydrated uranyl oxide: Curite, Polyhedron 26 (2007), pp. 3724-3730.

[9] W.H. Zachariasen, Crystal chemical studies of the 5f-Series of elements. I. New structure types, Acta Crystallogr. 1 (1948), pp. 265-268.

[10]H.R. Hoekstra and S. Siegel, The uranium-oxygen system: U3O8-UO3, J. Inorg. Nucl. Chem. 18 (1961), pp. 154-165.

[11]B.O. Loopstra, Neutron diffraction investigation of U3O8, Acta Crystallogr. 17 (1964), pp 651-654.

[12]B.O. Loopstra, The Phase transition in $\alpha-\mathrm{U} 308$ at $210^{\circ} \mathrm{C}$, J. Appl. Cryst. 3 (1970), pp. 94- 95.

[13]H.R. Hoekstra and S. Siegel, The uranium trioxide-water system, J. Inorg. Nucl. Chem. 35 (1973), pp. 761-779. 